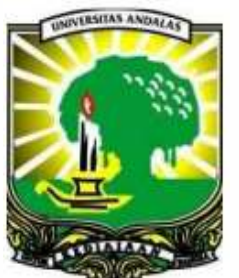

Available online at http://ijasc.pasca.unand.ac.id

International Journal of Agricultural Sciences Graduate Program Universitas Andalas

Journal homepage: http://ijasc.pasca.unand.ac.id

\title{
Agricultural Development through Regional Approach: A Case Study in Poultry Production Central Area in Mungka Sub-district, Lima Puluh Kota District
}

\author{
Sri Endang Kornita ${ }^{a *}$, Sjafrizal $^{b}$, Helmi $^{c}$, Asdi Agustar $^{d}$ \\ ${ }^{a}$ Graduate Program, Universitas Andalas, Kampus UNAND Limau Manis, Padang, West Sumatra 25163, Indonesia

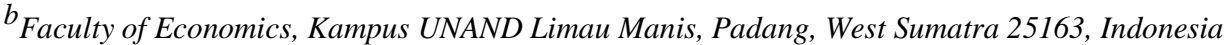 \\ ${ }^{c}$ Faculty of Agriculture, Kampus UNAND Limau Manis, Padang, West Sumatra 25163, Indonesia \\ ${ }^{2}$ Faculty of Animal Husbandry, Kampus UNAND Limau Manis, Padang, West Sumatra 25163, Indonesia
}

\section{ARTICLE INFO}

\section{Article history:}

Received 26 October 2017

Received in revised form 30 March 2018

Accepted 06 April 2018

Keywords:

Production center area, aglomeration profit. location

\begin{abstract}
A B S T R A C T
The regional approach in agricultural development has only been limited to the concept and has not been implemented in real terms. Various forms and models of agricultural development policy using the regional approach cannot prove that the indicators of regional approach have existed and been applied in agricultural areas. The development of agriculture so far has only been sectoral. This indicates that the concept of agricultural development through regional approach has not been implemented in real condition. In development through regional approach, the synergies among sectors and among economic activities are compulsory. The production central area (PCA) approach is one of the agricultural development approaches based on regional economic development theory. This research aimed to assess how area production center as a model of agricultural development that had considered regional concept, could be success in developing regions. The respondents were layer hen breeders residing in PCA location and Non PCA (50 respondents each).The study reveals that the value of agglomeration profits of large scale economies (SEI), localization economies (LEI), capital and labor showed positive and significant effects on layer hen production at PCA location. To further increase commodity production in PCA, the agglomeration profits as a regional approach variables should be part of the PCA analysis to improve productivity, efficiency and provide added value for farmers/breeders.
\end{abstract}

\section{Introduction}

The regional approach in agricultural development has only been limited to the concept and has not been able to be implemented in real terms. Various forms and models established as a form of agricultural development policy using the regional approach are not able to prove that the indicators of the regional approach have been existed and implemented in the agricultural areas.

\footnotetext{
* Corresponding author

E-mail address: cei.ajha@gmail.com.
} 
The policy in deciding one region to be a center of activity or production for agriculture and nonagriculture or other economics, theoretically leads to the thought of regional economists, especially location theory. One of the forerunners of the location theorist was from Germany, Von Thunen (1851), who discussed the location-based analysis of agricultural activities in Europe. This theory was further developed by William Alonso (1964) as the foundation of land-use theory in urban areas. Then, at the time of the industrial revolution in Germany began to emerge, Alfred Weber (1929), wrote a book about the theory of industrial location by taking the case of choosing the location for the establishment of a steel factory to meet the demand of the railway industry. This theory was further developed by Edgar Hoover (1948) and Leon N. Moses (1958). In addition, August Losch (1954) also started to analyze the location of a company based on the concentration of demand and interregional competition (Spatial competition). This theory was further developed by Grennhut and Ohta (1975) into a broader framework of analysis on the spatial price theory and market area (Sjafrizal, 2008).

The main objective of regional development is to harmonize various sectors and regional development activities, so that the utilization of the resources and space within them can optimally support people's lives (Ambardi, 2002). Production Central Area is an application form of agricultural development through regional approach where the synergy becomes the requirement for the development of the PCA so that agglomeration of agricultural development that occurs will increase the welfare of farmers. The development of agricultural sector through regional approach in developing agricultural production central area should be integrated and linked to other sectors. However, in reality the activity is still running partially so that the backward and forward linkage in regional economic activity have not been done optimally, so now many production centers can not run as planned. This means that synergy and functional integration among sectors expected to occur with the establishment of PCA have not been able to be implemented. One of the PCAs that is still running now is the PCA of layer hen poultry in
Mungka sub-district, Lima Puluh Kota district which is the location of this study.

So far, researches that have been done on PCA are about land suitability and development program of PCA (Stiawan, 2000); identification of PCA development (Faperta and Kehutanan UNHAS, 2000); community participation in the development of PCA (Study Team P4W-IPB, 2001); agricultural commodity transport route (Muhammad, 2005); farmers' income and land prices (Mulyani, 2007); and PCA sustainability index (Iswari, 2008). Further, Kemal (in Prismuladi, 2006), did research in PCA of layer hens in Bengkalis district and stated that the production center provided profits for the farmers in the form of scale and localization profit, and joint facilities after they were grouped. However, whether the profits of production increase are truely due to the presence of farmers in the central location or profits obtained might not be different compared to when the farmers are not in the central location. This thing is not discussed in this study.

This study provides a scientific contribution to the concept of agricultural development through regional approach. Discussion of the research is based on two things. First, the research is focused in Production Central Area as a form of agglomeration in agricultural development. Second, this research also contributes to the importance of the implementation of agricultural development through regional approach, and can be used as a reference for more successful development of the area (especially agricultural areas). This research describes the regional approach in contextual agricultural development. A study of regional development is based on real regional economic development activities that appears to be unclear if linked to existing concepts and theories. The objectives of this research are: (a) Analyzing scientifically the determination of Mungka subdistrict as a PCA for layer hen poultry in Lima Puluh Kota District using location theory approach; (b) Measuring and analyzing the agglomeration profits obtained in the poultry PCA in Mungka; (c) Measuring and analyzing the effect of agglomeration profits, capital and labor on layer hen poultry production in PCA Mungka; (d) Analyzing the policy implications of the study 
results on the increase of layer hen poultry production in PCA Mungka.

\section{Research Methods}

Agricultural development policy through regional approach is an effort made to optimize the utilization of space in developing agriculture by utilizing synergy and sectoral and regional interconnection. The optimization of spatial utilization means that the space utilized must be such that it does not cause an imbalance in a region, does not damage or cause loss of ecosystem functions that support the survival of life, and encourages the realization of synergy between sectors as well as between one region and others. Thus, the effectiveness of a regional development does not only gives goodness to the community from spatial planning, but also to other components of the region in the broad sense, ecosystem of region.

In this context, the approach of regional development can be seen from several aspects, namely the implementation (level of effectiveness and efficiency in the social sectoral activities), and institutional aspects (harmonious and balanced mechanisms and institutions). The effectiveness of regional development can be realized by consistent implementation of the above aspects, so as to give the effect of economic sectorally and community socio-economic in a region. At the applicative level, the regional development approach is realized in the form of designation of a certain area for certain activities such as the production central area which has important pillars (concentration, linkage and efficiency) as the base of agglomeration, so there are agglomeration profits in the area which in turn will be able to make the main commodity of PCA as a driver for social economy.

The determination of a region should consider that space is a place for socio-cultural and economic activities of the community, which has unequal limitations and development opportunities. The high dynamics of space needs in order to accommodate the interests of government, private and public investment, demands the existence of a spatial plan that can accommodate the interests of various stakeholders. The research flow chart is presented in figure 1

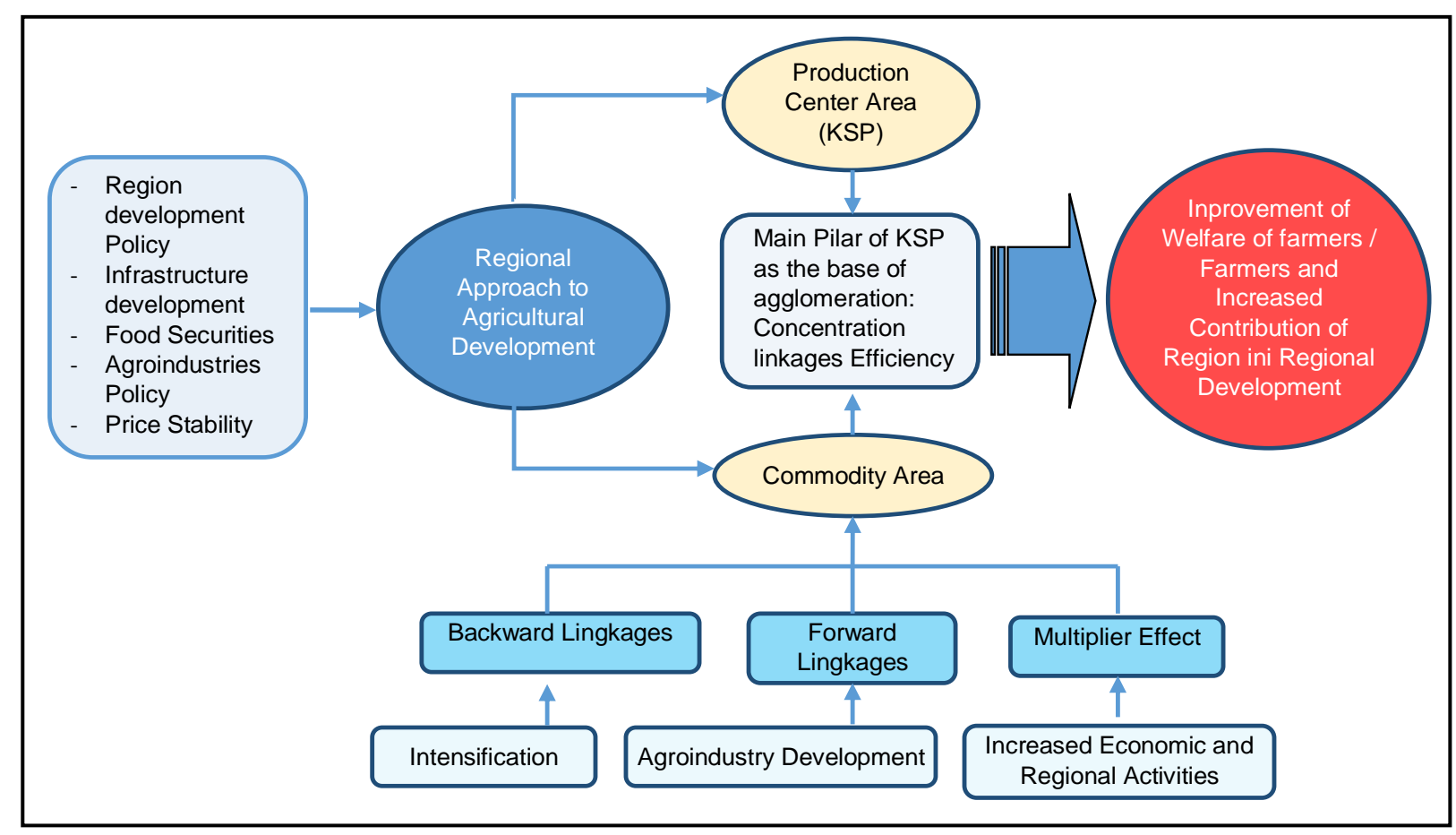

Figure 1: Research Flow Chart 


\subsection{Sample, Location and Time of Study}

Research on agricultural development through regional approach at Poultry Production Center in Mungka Sub-district, covered the elements: identification of agricultural commodities related to poultry in production center area as the core of community economic movement, analyzing the agglomeration profits in the area of production centers (the effect of agglomeration profit, capital and labor for increasing production), and policy implications of study results on regional approach models in agricultural development for developing production centers.

To focus the results, the research was conducted in Poultry Production Center in Mungka sub-district, Lima Puluh Kota District from March 2016 until April 2017. The Poultry Production Center was still running at the time of research as a form of regional development in West Sumatera Province.

The population of this study consisted of poultry breeders at the location of PCA Mungka and poultry breeders outside or around PCA (Non PCA), namely in the areas directly adjacent to the areas specified by the government as PCA. The number of poultry breeders in Mungka Sub-district was 3,028 family heads. The adjacent subdistrict to Mungka (PCA) which is not the center of poultry production in the District of Lima Puluh Kota is Suliki subdistrict (Livestock and Animal Health Service of Kabupaten Lima Puluh Kota, 2015). Samplings of farmers/breeders as the respondents of the research were taken by quota sampling method consisting of 50 poultry farmers at PCA location and 50 poultry farmers at Non PCA location. Samples were taken using purposive random sampling.

\subsection{Method of Analysis}

In general, this research was conducted using two methods, desk and field research. Desk method used secondary data, while field research used primary data collected at the research location.

In this analysis the site selection was determined based on Weber's principle of transportation orientation. Profits of location and agglomeration were calculated based on Isard
(1960) in Sjafrizal (2012), that the profits covered 3 main elements: Large Scale Economies, Localization Economies, and Urbanization Economies. To measure and analyze the effect of agglomeration profits, capital and labor on the production of layer hen poultry in PCA Mungka, the multiple regression analysis with SPSS ver 23 was used. Equation model is formulated as follows:

$$
Y=\beta_{0}+\beta_{1} X_{1}+\beta_{2} X_{2}+\beta_{3} X_{3}++\beta_{4} X_{4}++\beta_{5} X_{5}+e
$$

Where :

$\mathrm{Y}=$ Production of Poultry Livestock in PCA (Million Rp)

$\beta 0=$ Constants

$\beta 1=$ Regression coefficient of Large Scale Economies (SEi)

$\beta 2=$ Regression coefficient of Localization Economies (LEi)

$\beta 3=$ Regression coefficient of Urbanization Economies (UEi)

$\beta 4=$ Capital regression coefficient

$\beta 5=$ Labor regression coefficient

$\mathrm{X} 1$ = Large Scale Economies (the profits gained in the form of decreased average production cost per unit)

$\mathrm{X} 2$ = Localization Economies (the profits gained from the transport cost savings for both raw materials and production)

X3 = Urbanization Economies (the benefits arising from the use of shared facilities)

X4 = Capital (Million Rp)

$\mathrm{X} 5=$ Labor (Number of people as labor)

$\mathrm{e}=$ error term in linear equations

Hypothesis testing was statistically performed by using $\mathrm{t}$ test and $\mathrm{F}$ test. The analysis of the policy implications of the study results in increasing the production of layer hen poultry in PCA Mungka and analysis of agricultural development through the Regional Approach were done by qualitative methods on the important pillar of PCA as the foundation of agglomeration occurence and as the main condition discussed in this study as synthesis. 


\section{Results and Discussions}

\subsection{Research results}

\section{A. Weberian Locational Weight Calculation}

Determination of Mungka subdistrict location based on site theory needed to be analyzed because the location of the PCA that was established based on the decree of head of region, also needed to know its scientific suitability based on the theory of least cost theory location pioneered by Alfred Weber. According to Weber (in Sjafrizal, 2012), the selection of the location for economic activity is determined by the ratio of the cost of transporting raw materials per ton or kilogram kilometer, where site selection is based on the principle of minimum transportation cost (transportation orientation).

Weber's analysis was used to analyze the location of PCA Mungka which had been determined by Decree of regent of Lima Puluh Kota. The determined location of PCA connects between the location of raw materials/inputs and the market. The information about the origin of inputs and marketing for egg production in PCA layer hen poultry in Mungka was obtained from the data of key informants (business actors and the Association of Poultry Farmers and Poultry Shops). The main source of input of DOC (Day Old Chiken) was obtained from Medan, with the transport cost to PCA Mungka was Rp.2,500,000, per 10,000 individuals doc (100 boxes, each contained 100 doc ( $\operatorname{Rp} 250$ /individual doc). The main feed source was from Lampung with the transportation cost Rp.2,400,000, - for the amount of feed weight of 8 tons (Rp.300/kg). The marketing areas of egg production from PCA Mungka were local area (West Sumatera), Riau, Jambi and DKI Jakarta. The calculation of the transportation cost for local (West Sumatra $=20 \%$ ) from the sale price of cage Rp.970 (the price of April 2017) to Rp.1.000 which meant Rp.30 per item, while for marketing area of Riau (50\%) and Jambi $(20 \%)$ egg price plus $10 \%$ transport cost, while for DKI Jakarta (10\%) transportation cost plus $20 \%$ of egg price. The data can be seen in Table 1.
Table 1. Weberian Locational Weight Calculation of KSP Mungka

\begin{tabular}{lr}
\hline \multicolumn{1}{c}{ Description } & \multicolumn{1}{c}{ Value } \\
\hline Total Production Cost (Million Rp) & $8,335.44$ \\
Total Production (Million Rp) & $13,901.51$ \\
Input coefficient (Total Input /Total & 0.60 \\
Output) (a) & 289.00 \\
Transportation cost of input (n) & 104.50 \\
Transportation cost of output (m) & 1.66 \\
Weberian locational weight (W= an/m)
\end{tabular}

Weberian Locational Weight calculation was done using the formula $\mathrm{W}=\mathrm{an} / \mathrm{m}$, and the results obtained was 1.66. According to Weber's theory, when the value of $\mathrm{W}>1$ (1.66), it is categorized as Weight Loosing Industry, where the input for each unit of output is heavier than the output. The best location as the optimal location is near the raw material/input. Therefore, with the establishment of Mungka District as the location of PCA of layer hen poultry, then both the government (related institutions) and business actors should concerned more about the need to develop the main source of raw materials for PCA development to be more integrated by developing upstream business related to poultry, among others it needs to develop source of raw material for main feed that is corn.

\section{B. Calculation of Agglomeration Profits}

Theoretically, the production center as a model of agricultural development through a regional approach should fulfill the agglomeration profit elements. To know and analyze them, the location and agglomeration profits were calculated according to Isard (1960) in Sjafrizal (2012), the profits cover 3 (three) main elements: (1) Large Scale Economies, the profits gained in the form of decreased average production cost per unit, because production is done on a large scale; (2) Localization Economies, the profits gained from the transport cost savings for both raw materials and production, arising from being concentrated in a production center; (3) Urbanization Economies, the benefits arising from the use of shared facilities.

From the results of data collected on 100 farmers/breeders of layer hen poultry consisting of 50 respondents of PCA and 50 respondents of Non 
PCA, the calculation of agglomeration profits obtained were as follows:

Table 2. The Calculation Result of Agglomeration Profit at KSP Mungka

\begin{tabular}{|l|r|r|r|}
\hline $\begin{array}{l}\text { Agglomeration } \\
\text { Profits }\end{array}$ & Non KSP & KSP & $\begin{array}{c}\text { The } \\
\text { calculation of } \\
\text { agglomeration } \\
\text { profit }\end{array}$ \\
\hline $\begin{array}{l}\text { Large Scale } \\
\text { Economies }\end{array}$ & $24.565,63$ & $16.365,34$ & $8.200,29$ \\
\hline $\begin{array}{l}\text { Localization } \\
\text { Economies }\end{array}$ & 452,96 & 344,99 & 107,97 \\
\hline $\begin{array}{l}\text { Urbanization } \\
\text { Economies }\end{array}$ & $\mathrm{NA}$ & $\mathrm{NA}$ & $\mathrm{NA}$ \\
\hline
\end{tabular}

From the above calculation results, if $\mathrm{SEi}>0$ then 8,200,29> 0 or AC non PCA> AC PCA, it was seen from the average cost of non PCA breeder $=$ Rp. 24,565,63/monthly output (per egg was $24,565,63 / 30=\mathrm{Rp} .818,85)$ whereas at poultry breeders of layer hens at PCA location = Rp16,365.34/monthly output (per egg was Rp.16,365,34/30 =Rp. 445,51). The estimated value of the agglomeration profit of large-scale profit components showed that the layer hen breeders at PCA locations were more profitable because in the management of the average production cost incurred by farmers was lower and more efficient than the non-PCA breeders.

Furthermore, by using the same method, the measurement of the amount of localization benefits generated was done by using the following formula:

$$
\mathrm{LEi}=\mathrm{TR} \text { non PCA }- \text { TR PCA. }
$$

From the above calculation results, if $\mathrm{LEi}>0$ then 107.97> 0 or TR non PCA> TR PCA seen from the average cost of transportation of non breeders of PCA = Rp. 452,96/kg whereas the one of poultry breeders of layer hens at location of PCA=Rp.344,99/kg. The estimated value of the agglomeration profits of components of localization profits showed that layer hen breeders at the PCA location were more profitable because transportation cost per kilogram was lower and more efficient than that of non-PCA breeders. Urbanization Economies did not occur in the location of PCA Mungka. The results of field research and discussions and interviews with business actors, governments, associations, and policy makers of the relevant agencies, showed that there were no shared facilities such as warehouses, electricity, clean water or non-financial institutions (such as cooperatives) and breeder farmer groups in PCA Mungka.

\section{Regression Analysis and Hypothesis Test}

Multiple linear regression analysis was used to measure the effects of independent variables to dependent variables and to determine the independent variables that most influential on dependent variables. This research showed the effect of agglomeration profits, capital, and labor at poultry production of layer hens in PCA Mungka . The calculation in the study was done by using SPSS program version 23. The result of multiple regression analysis is presented in Table 3.

Table 3. Results of Multiple Regression Analysis

\begin{tabular}{|r|r|r|r|}
\hline \multicolumn{1}{|c|}{ Variabel } & \multicolumn{1}{|c|}{$\begin{array}{c}\text { Koefisien } \\
\text { Regresi }\end{array}$} & t hitung & \multicolumn{1}{c|}{ Sig. } \\
\hline (Constant) & $-78,460$ & $-3,842$ & 0,000 \\
\hline X1 & 0,003 & 3,141 & 0,003 \\
\hline X2 & 0,378 & 2,382 & 0,021 \\
\hline X3 & 1,516 & 23,404 & 0,000 \\
\hline X4 & 9,452 & 2,055 & 0,046 \\
\hline R Square $=0,986$ \\
F Hitung $=874,449$ \\
F Sig = 0,000 \\
\hline
\end{tabular}

From the above data multiple regression equation could be made as following:

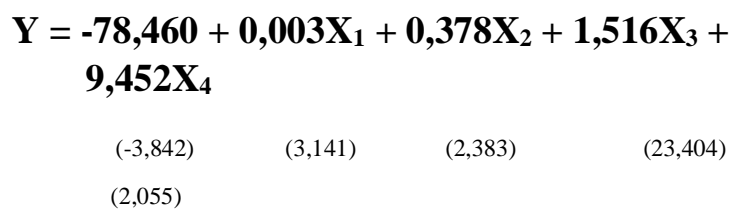

The above equation explains that constant value $\beta 0=-78.460$ which means if all independent variables, agglomeration profits of large scale economies (X1) and localization economies (X2), capital and labor are considered constant, then poultry production of layer hens at PCA locations calculated by the value of their production produced within the PCA area for a month, the production decreases by 78.460 million rupiahs per month. Coefficient value of $\beta 1=0.003$ means if the value of agglomeration profits of large scale 
economies (X1) increases by 1 point which means there is an increase in profit difference between located in PCA compared to located outside PCA, thus the production also increases 3 folds with an assumption that other variables are considered constant. This indicates that agglomeration profit of large scale economies (SEi) is positively related to the value of poultry production of layer hens at PCA location. The coefficient value of $\beta 2=0.378$ means if the agglomeration profit of localization economies (LEi) (the difference of transportation cost between located in PCA and outside PCA) increases by 1 point, then the poultry production of layer hens in PCA Mungka also increases by 37.8 folds of the profit. Assuming other variables are constant , Localization Economies (LEi) is positively related to the poultry production of layer hens at PCA location. Coefficient value of $\beta 4=$ 1.516 means if capital increases by 1 point then poultry production of layer hens at PCA Mungka also increases by 1.516 folds from the additional capital. Assuming other variables are constant, then the capital is positively related to the poultry production of layer hens at the location of PCA. Coefficient value of $\beta 5=9.452$ means if the labor increases by 1 person then the poultry production of layer hens at PCA Mungka also increases by 9.452 folds from the increase in the number of labors. Assuming other variables are constant, then labor is positively related to the poultry production of layer hens at the location of PCA. Hypothesis was tested using $\mathrm{F}$ and $\mathrm{t}$ Test.

From the result of $\mathrm{F}$ test, it could be concluded that at level of significance $95 \%$, all independent variables, agglomeration profits of large scale economies and localization economies, capital, and labor, showed significant effects on dependent variables, poultry production of layer hens at PCA location. Further more, based on the $t$ test at the level of significance 95\%, agglomeration profit of large scale economies (X1) on the poultry production of layer hens at PCA Mungka showed a significant effect. Based on the results obtained the counted $t$ value of variable agglomeration profit of localization economies ( X2) with a significant level of $95 \%(\alpha=5 \%)$ was 2.382 with the probability level (sig) was $0.021<0.05$. So, H0 was accepted and $\mathrm{Ha}$ was rejected. It was concluded that at the level of significance $95 \%$ the agglomeration profit of localization economies (X2) showed a significant effect on the poultry production of layer hens at the location of PCA Mungka. The counted $t$ value of capital variable with a significant level of $95 \%(\alpha=5 \%)$ was 23.404 and the probability level (sig) was 0.000 , counted $\mathrm{t}>\mathrm{t}$ table means $\mathrm{H} 0$ is accepted and $\mathrm{Ha}$ was rejected. It was concluded that at significance level of $95 \%$, capital (X4) had a significant effect on the poultry production of layer hens in Mungka. Similarly, counted $t$ value of labor variable (X5) with a significant level of $95 \%(\alpha=5 \%)$ was 2.055 with the probability level (sig) was $0.046<0.05$, which meant that $\mathrm{H} 0$ was accepted and $\mathrm{Ha}$ was rejected. It was concluded that at significance level of $95 \%$, labor (X5) had a significant effect on the poultry production of layer hens at the location of PCA Mungka.

\subsection{Discussions}

\section{A. Location Analysis of PCA Mungka}

In this research, it is known that the determination of Mungka Sub-district as one of the Poultry Production Center of layer hens by the Regent of Lima Puluh Kota has been appropriate based on real condition and a scientific study using regional economic approach. The result of analysis based on Weber's theory with the value of $\mathrm{W}>1$ that was 1.66, meant Weight Loosing Industry, where the input for each unit of output was heavier than the output. The exact location as the optimal location is near the raw material/input. The government or related agencies and business actors (farmers) in the future should pay more attention to the needs for developing the main sources of raw materials for PCA development to be more integrated by developing upstream and downstream industries related to layer hen farming. Development potential for the main feed source of raw materials is corn commodity. Indeed, in Mungka sub-district corn farming for animal feed has been developed but it is still very limited and due to the very low price of corn coming from other areas (Lampung and Pasaman), the farmers in this area tend to buy feed from outside instead of planting them. Related to that facts, the role of government in agricultural development integrated 
with upstream and downstream industries becomes very important. A better synergy is needed in regional development in Mungka sub-district as the location of PCA of layer hen poultry. This is also in line with the increasing need of community for protein (egg).

Basically the determination of Mungka subdistrict as a location of PCA of layer hen poultry has been appropriate by considering:

1. Most of the poultry farmings in this area have been passed down by the families of the local people. In average, the generation now has been in the 3rd generation since the effort pioneered by their parents).

2. The availability of lands and land suitability are sufficient for poultry and corn farmings in this area, and also other inputs such as bran for animal feed in this area are available.

3. Downstream industries related to the eggs packaging containers have been available in Nagari Jopang Manganti which is able to produce 15,000 pieces of egg containers per day and have been operating since 2011, and until now have become the main supplier of eggs containers in PCA Mungka.

4. Industries for producing cages from wire for hens have been developed in Mungka and they are prospective to be developed by the community in this area because local production has not been able to meet the needs of farmers in this area.

Related to this, it is in line with Kay's opinion in Prayitno and Arsyad (1986), that the planning/development of farming depends on the resources. The type and quality of resources determine what farming type will be undertaken. There are four resources as important factors of farming: (1) land, covering quantity (width) and quality, (2) manpower, including quantity and quality, (3) capital, including fixed capital (land, machine, building, inventory) and working capital for purchasing input variables, and (4) management skill of farmers.

In line with the above opinion, the main problem for developing poultry farming business in Mungka District is mainly related to business management. Most breeders run their business based on the experience of their parents and business management is still done with the family management system. Related to this matter, the role of government in conducting human resources training to improve business management quality can be a concern in the future so that PCA can develop better and more concentrated for improving the prosperity of the population in this region. Other problems faced by farmers are environment and natural conditions where hens mortality is higher than normal condition and the instability of feed prices (bran and corn) in rainy season. Farmers are one of the agribusiness activists who are still the biggest contributors in the economy in Lima Puluh Kota District, so the government should pay more attention to their needs, so that the development of poultry as a part of the agricultural sector can be more successful and would be no failure in the development of PCA in this area.

In line with the research conducted by Yusdja et. al. (2004), the failure of the government in fostering small businesses (poultry) including layer hens in Indonesia is caused by the government does not consider the importance of farmers in the economy, instead the most important thing is how to overcome unemployment by making farming business as one absorber of labor. So, in the development of layer hen farming business there should be an integration of three business actors (breeders, fish seeders, and feed company etc.) as it is shown in figure 2 .

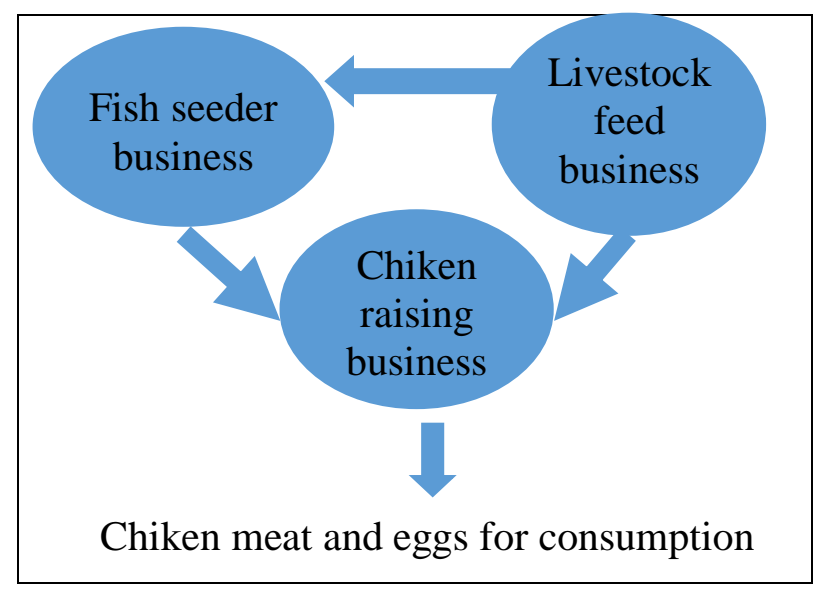

Figure 2. Business Concept of broiler and layer hens (adapted from Yusdja et al, 2004)

In the case of such development, the role of government as policy maker in agricultural 
development becomes very important that is not known by farmers in the location of PCA Mungka. The example of government's role in establishing poultry business is the government's policy in China (after the avian influenza outbreak in 2004), where the government as a policy maker then establishes clusters and provides various infrastructure such as roads, electricity, water supply and waste facilities (as joint facilities in the cluster area) (Wang et. al. in Ilham, 2015).

\section{B. Agglomeration Profits}

Related to the existing agglomeration profits in the location of PCA, theoretically the production center as a model of agricultural development through a regional approach should meet the agglomeration profit elements. These profits include 3 (three) main elements: (a) Large Scale Economies; (b) Localization Economies; and (c) Urbanization Economies. From the results of field research, there are only two agglomeration profits occuring in PCA Mungka, Large Scale and Localization Economies. While the Urbanization Economies does not occur because of the lack of joint facilities used by poultry business actors in the location. The estimated value of the agglomeration profit of large-scale profit component shows that layer hen breeders at the PCA location are more profitable because in average production cost is lower and more efficient compared to those of non-PCA breeders. The estimated value of agglomeration profit component of localization profit also shows that layer hen breeders at PCA location are more profitable because transportation cost per kg is lower and more efficient than those of nonPCA breeders. This can happen because of many breeders in the location of PCA concentrated in one area causes the transportation cost cheaper due to the process of transporting inputs and output production can be done using the means of transportation with full capacity. Production inputs in the form of DOC and livestock feed which are still mostly from other regions can be ordered by the breeders through Poultry shop in PCA with lower price than the one located outside PCA due to high demand (concentration of demand is due to the concentration of livestock activities of layer hens) inside the PCA location, so that the supplier companies offering poultry feed ingredients want to provide facilities or price discount on the products offered in marketing at the location of PCA and deliver feed to the location of PCA.

As Kotler (1997) argues, in the marketing process of a product, marketing management is required. Marketing management are analyzing, planning, implementing and supervising programs aimed at exchanging with the intended market to achieve organizational goals. It is known that the main purpose of a company is profit. So, according to him, "A product is something that can be offered to a market for attention, acquisition, use, or consumption and that might satisfy a want or need."

Related to urbanization economies that was not found because of the absence of joint facilities used by poultry business actors in the PCA location, then the role of government is very important both in establishing institutional and joint facilities for the development of this area as PCA to be able to improve the welfare of the population and play a role in regional development. In line with the research of Stiawan (2000), in the development of PCA, the development programs on physic, facilities and infrastructure become important, in addition to institutional development programs, human resources and technology. Saefullah (1994) also stated that in regional development an integrated policy strategy is required between rural and urban development, where government intervention is needed to accelerate development.

\section{Effect of Agglomeration, Capital, and Labor Profits}

To produce a product hence requires factors of production. This study analyzes the effects of capital and labor along with agglomeration profit occuring in PCA Mungka in increasing production. Production cost/capital is one of the production factors used in the production process. Labor is one of the most important factors in the production process to produce goods and services in addition to capital and technology. In PCA Mungka, production of layer hens is still influenced by large scale and localization agglomeration profits, capital and labor, so that any increase in agglomeration profits on capital and labor will increase significantly the production of layer hens in this 
area. Egg production is still very prospective and becomes the main food source of protein of the population in Indonesia. According to Malthus in Lopang (2016), population growth is much faster than foodstuffs. As a result there will be a big difference between the population and their needs. Malthus's theory is that the population tends to increase geometrically, while their needs increase arithmetically. So, it is concluded that population growth is faster than foods required, so that to fulfill the requirement the government requires continuous production. Capital and labor have a dominant role in the production of poultry of layer hens in PCA Mungka. So, from the results of multiple regression calculations it can be stated that in addition to big capital requirement in its management, layer hen farming in PCA Mungka is also very dependent on labors. This is understandable because most of the agricultural sectors (including animal husbandry) in Indonesia are still done manually/semi manually.

\section{Policy Implications of Study Results}

From the results of research, it can be stated that the development of agriculture through regional approach in the form of PCA should be developed for increasing production in poultry farming of layer hens in Mungka. The main pillar of PCA as the basis for its development is agglomeration profit. With the profit it will be seen that production activity/farming/livestock business is more focused than at non-PCA location. In addition, there are interrelationships in the economic activities of the population at the location of PCA compared to non-PCA. The development of production is more efficient and effective at locations of PCA compared to non PCA locations. The agglomeration profit in PCA Mungka significantly influences the production of layer hen poultry in this area. However, if the existing agglomeration profit is not increased by various parties concerned, government, farmers, other business actors, and communities, it is doubt that the impact will be less in the development of the region. Many locations of PCA in rural areas that are no longer running due to reduced agglomeration profit and PCAs only become the name of the region when no longer have differences in the agglomeration profit from non PCA areas. This can happen as Iswari's study (2008), that from his research on the PCA sustainability index in Agam District, it is included in the non-sustainable category. So, if we look at PCA as one form of agricultural development through regional approach, the role of all parties is needed for its sustainability.

In this regard, development of PCA Mungka requires government policy in regional development, especially in facilitating the formation of agglomeration profit of urbanization economies. In addition, improving the quality of breeders through institutional development and business management requires government intervention primarily through inter-sector synergy for improving production and better farmer's welfare. Based on the results obtained from this research, the existing agglomeration profit in PCA provides benefits for the region. These benefits include:

a. Productivity. If productivity increases then the agglomeration profit obtained by the region also increases. With increasing productivity, the sustainability of the region as a production center will continue to prosper the community. The value of productivity can be seen from the comparison of egg production in PCA and Non PCA

Table 4. Productivity of layer hens

\begin{tabular}{lccc}
\hline Location & $\begin{array}{c}\text { Egg } \\
\text { Production per } \\
\text { month }\end{array}$ & $\begin{array}{c}\text { Number of } \\
\text { chicken }\end{array}$ & $\begin{array}{c}\text { Productivity } \\
(\%)\end{array}$ \\
\hline PCA & $14,331,450$ & 513,350 & 93.06 \\
Non PCA & $8,137,350$ & 316,000 & 85.84 \\
\hline
\end{tabular}

From the table above we can see that the productivity of layer hens is higher in PCA than in non PCA. Therefore, the government should pay more attention to the farmers in PCA locations so that if the agglomeration profit increases, then the production will also significantly increase as well. Thus, the production of eggs in the PCA will increase so that it will improve the welfare of farmers. 
b. Efficiency. It can be seen from the transportation cost. From the cost savings of transportation at the location of PCA, it can be calculated how much profit can be obtained if raw materials (which currently require transport costs from outside the region) are produced in the region. As an illustration it can be seen in Table shown below).

Table 5. Saving on transportation cost from producing DOC and feed

\begin{tabular}{lrr}
\hline \multicolumn{1}{c}{ Description } & $\begin{array}{c}\text { Mungka Sub } \\
\text { District }\end{array}$ & \multicolumn{1}{c}{$\begin{array}{c}\text { Lima Puluh } \\
\text { Kota Regency }\end{array}$} \\
\hline $\begin{array}{l}\text { The need of DOC based } \\
\text { on number of layer hens }\end{array}$ & & \\
in 2015 & $975,620.00$ & $5,061,375.00$ \\
$\begin{array}{l}\text { Saving of transportation } \\
\text { cost if DOC produced in }\end{array}$ & & \\
$\begin{array}{l}\text { PCA (Million Rp) } \\
\text { The need of feed (tonne) }\end{array}$ & $106,830.39$ & $554,220.56$ \\
$\begin{array}{l}\text { Saving of transportation } \\
\text { cost if feed produced in }\end{array}$ & & \\
PCA (Million Rp) & $32,049.12$ & $166,266.17$ \\
\hline
\end{tabular}

From the above calculation, it is reasonable if the local government begins to consider the development of chicken poultry input investment in Kabupaten Lima Puluh Kota, especially in PCA Mungka. If it can be realized it will bring multiply effects on labor, relevant industries and will certainly increase community welfare, especially breeders/farmers.

c. Added Value. The added value existing in the region will increase if productivity and efficiency can go together. The added value is the difference of the output from the input value, while in equating the value of the calculation of added value distribution, the calculation was done by equivalence through output production (egg). Based on field research on layer hen farms in Kabupaten Lima Puluh Kota, the value chain consists of poultry shop (PS), breeders, collecting traders, wholesalers, small traders, and consumers.

Along with the growing of agribusiness technology of agriculture and livestock and the increasing of society demand on egg protein, hence layer hen poultry still has good prospect for improvement of farmer's prosperity. Institutional development of farmers with government support and sustainability of PCA is needed very much in agricultural development. Related to the case, this research has explained that agricultural development with regional approach should be used as reference for future agricultural development area. The main elements of the regional approach will support the sustainability of activities in the region for community economic and regional development.

\section{Conclusion}

Based on the results of analysis relating to the objectives of research done, conclusions can be drawn as following:

a. Determination of Mungka Sub-district as a production center area (PCA) of layer hen poultry in Lima Puluh Kota District is appropriate based on location theory approach, which is based on the result of Weber Weight Loosing Industry theory. The optimal location should be near raw materials/input.

b. There are two out of three agglomeration profits obtained in the PCA of layer hen poultry in Mungka, namely large scale and localization economies. So, the requirements of area approach in agricultural development in PCA Mungka with the existence of agglomeration profits can be fulfilled.

c. The agglomeration profits, capital and labor, based on $F$ test and $t$ test show significant effects and positive relation on the value of layer hen poultry production in Mungka . So, the increase in independent variables also increase the dependent variable (poultry production value), but with the negative value of constant, it means there will be production decrease when the independent variable does not change.

d. Policy implication of the study result is that agricultural development through regional approach is a model of agricultural development that must be done in order the sustainability of agricultural commodity development areas keep growing. This can be realized better by increasing agglomeration profit, so that PCA production value can be further increased. This 
will provide advantages to the area in the form of benefits on productivity, efficiency, and added value.

\section{Recommendation}

Based on the above conclusions, the recommendation given are as follow:

a. The agricultural development model through regional approach should be continuously applied with the active role of all parties so that the sustainability of PCA can be maintained and developed. For that reason, the role of government, private business actors, and community should be in synergy in doing the activities of PCA. Related to the implementation of the policy, it is expected that the government further increases the production of PCA, develop the facilities and infrastructure in PCA Mungka mainly related to agglomeration profits through the provision of joint facilities both physically and institutionally, as well as human resources and technology development.

b. Agricultural development through regional approach in PCA should have an important pillar for sustainability in the future, namely the existence of agglomeration profits in the area which will be seen from the concentration of production/farm/livestock production activities which are more focused than in the non PCA location. In addition, there are interrelationships in the economic activities of the population at the location of PCA compared to non PCA, as well as the development of more efficient and effective production at locations of PCA compared to non PCA locations. Therefore, the synergy among stake holders needs to be developed with the role of government as a facilitator.

c. Agricultural development through regional approach should be carried out by the government based on the potential that has developed in the existing area, so that the development will be faster to improve the welfare of the population in the region.

\section{References}

Ambardi. M. U dan Socia Prihawantoro (penyunting). 2002. Pengembangan Wilayah dan Otonomi Daerah Kajian Konsep dan Pengembangan. BPPT. Jakarta.

Azis, Iwan Jaya. 1993. Ilmu Ekonomi Spasial dan Relevansinya Dalam Perencanaan Pembangunan. dalam Ilmu Ekonomi Regional dan Beberapa Aplikasinya di Indonesia. LPFE-UI. Jakarta.

Badan Penelitian dan Pengembangan Pertanian Departemen Pertanian, 2008. Panduan Kerja Sama Kemitraan Penelitian Pertanian dengan Perguruan Tinggi. Jakarta.

BAPPENAS, 2005. Pengembangan Wilayah Strategis. Info Kajian BAPPENAS. Vol. 2 No. 2. Desember 2005. Jakarta.

Berry, B.J.L. dan A. Pred. 1961. Central Place Studies A Bibliography of Theory and Aplications. Regional Science Research Institute. Philadelphia.

Bryant, Coralie dan Louise G. White. 1989. Manajemen Pembangunan Untuk Negara Berkembang. Terjemahan Rusyanto. L. Simatupang. LP3ES. Jakarta.

Collier, W.L. 1993. A New Approach to Rural Development in Java: Twenty Years of Villages Studies. PT. Intersis Kelola Maju. Jakarta.

Christaller, W. 1966. Central Places in Southern Germany. Prentice Hall. Englewood Cliffs. New Jersey.

Departemen Pertanian , 2014. Strategi Induk Pembangunan Pertanian 2015-2045. Jakarta

Dillon, HS. 2004, Pertanian Membangun Bangsa dalam Pertanian Mandiri, Penerbit Penebar Swadaya. Jakarta.

Doughlas, M. 1998. A Regional network Strategy for Reciprocal Rural-Urban Lingkages: An Agenda for Policy Research with Reference to Indonesia. Third World Planning Review. Vol. 2 No. 1. 1998.

Dunn, William N. 2000. Analisa Kebijaksanaan Publik. Hanindita Graha Widia. Jakarta.

Faperta dan Kehutanan UNHAS. 2000. Identiikasi lokasi dan pengembangan KSP Propinsi Sulawesi Selatan. Makasar. 
Glasson, John. 1974. An Introduction to Regional Planning. Hutchinson \& Co (Publisher) Lth. London.

Hasan, 2003. Model Tata Ruang Kota Tani yang berorientasi Ekonomis dan Ekologis Studi Kasus di Kabupaten Gowa, Propinsi Sulawesi Selatan. Disertasi S3. PPs IPB. Bogor.

Hoover, Edgar. M., 1977. Pengantar Ekonomi Regional. Terjemahan Aditiawan Chandra. LPFE-UI. Jakarta.

Isard, W. 1975. Ecologic-economic Analysis for Regional Development. Free Press-Mac Milland. New York.

Iswari, Dwi. 2008. Indeks Keberlanjutan Pengembangan Kawasan Sentra Produksi Jeruk dengan Rap-Citrus Studi Kasus di Kabupaten Agam Sumatera Barat, Disertasi - Sekolah Pascasarjana IPB, Bogor.

Kornita, Sri Endang., Hainim Kadir., Lamun. 2007. Penelitian Komoditas Unggulan UMKM Provinsi Riau. Kantor Bank Indonesia PPSE Universitas Riau. Pekanbaru.

Kornita, Sri Endang. 2005. Revitalisasi Pertanian, Busung Lapar, dan Ancaman Rawan Pangan; Upaya Mengintegrasikan Pembangunan Pertanian dalam Kebijakan Ekonomi Makro. Artikel, Warta ISEI, Vol 2 - September 2006. Pekanbaru.

Kornita, Sri Endang. 2004. Pembangunan Wilayah dan Potensi Sinergi antar Kabupaten/Kota di Provinsi Riau. Tesis. PPs Unand. Padang.

Muhammad. 2005. Kebijakan Pengaturan Jalur Angkutan Umum Barang ke kota Solok dalam rangka Pengembangan Pasar bagi komoditi pertanian di Kawasan KSP. Pascasarjana-Unand. Padang.

Mulyani, Sri. 2007. Kajian terhadap Pendapatan Petani dan Harga Tanah di Kawasan Agropolitan, Studi Kasus di Kawasan Agropolitan Kecamatan Pacet dan Cipanas, Kabupaten Cianjur. Sekolah Pascasarjana-IPB, Bogor.

Nugroho, Iwan dan Rokhmin Dahuri. 2004. Pembangunan Wilayah: Perspektif Ekonomi, Sosial, dan Lingkungan. LP3ES. Jakarta.
Parr, JB. 1999. Regional Economic Development: An Export Stages Framework. Land Economics. 75 (1).

Prismuladi. 2006. Analisis Kebijakan Pengembangan Ayam Buras dan Implikasinya terhadap Pemberdayaan ekonomi Masyarakat. Tesis. PPs Unand. Padang.

Richarson, W. Harry, 2001. Dasar-Dasar Ilmu Ekonomi Regional. Terjemahan Paul Sitohang. LPFE-UI. Jakarta.

Rusastra, I W., P. Simatupang dan B. Rachman. 2002. Pembangunan Ekonomi Pedesaan Berbasis Agribisnis. Analisis Kebijakan: Pembangunan Pertanian Andalan Berwawasan Agribisnis. (Editor: T. Sudaryanto, et.al., 2002). Monograph Series No.23. Pusat Penelitian Sosial Ekonomi Pertanian, Bogor.

Rusastra, I Wayan. 2005. Kinerja dan perspektif Pengembangan Model Agropolitan dalam Mendukung Pengembangan Ekonomi Wilayah Berbasis Agribisnis. Pusat Penelitian Pengembangan Sosial Ekonomi Pertanian. Bogor.

Sjafrizal. 2001. Pembangunan Ekonomi Daerah dalam Era Otonomi. FE Unand. Padang.

Sjafrizal. 2005. Teori Pertumbuhan Ekonomi Regional dan Metode Analisis. PPs Unand. Padang.

Sjafrizal. 2008. Ekonomi Regional Teori dan Aplikasi. Baduose Media. Padang.

Sjafrizal. 2014. Ekonomi Wilayah dan Perkotaan. PT Rajagrafindo Persada. Depok.

Stiawan, Darma. 2000. Program Pengembangan KSP Provinsi Riau TA 1999/2000. Resident Consultant. Pekanbaru. Riau.

Sukirno, Sadono. 2002. Ekonomi Pembangunan. Fakultas Ekonomi UI. Jakarta.

Sukartawi, Rusmadi, dan Damaijati, E., 1993. Resiko dan Ketidakpastian dalam Agribisnis Teori dan Aplikasi. Raja Grafindo Persada, Yakarta

Suhandojo, 2001. Pemgembangan Wilayah Perdesaan dan Kawasan Tertentu: Sebuah Kajian Eksploratif. Badan Pengkajian dan Penerapan Teknologi. Jakarta.

Susilo, Y. Sri. 2002. Dampak Desentralisasi Fiskal Terhadap Kinerja Ekonomi Makro. Jurnal Kajian Bisnis Nomor 25 Januari- 
April 2002. STIE Widya Wiwaha. Yogyakarta .

Syafa'at Nizwar. 2000. Kajian Peran Pertanian dalam Strategi Pembangunan Ekonomi Nasional: Analisis Simulasi Kebijaksanaan dengan Pendekatan Imbas Investasi (Induced Investment). Disertasi S3. Program Pascasarjana IPB. Bogor.

Tarwiyanto, Junaidi. 2004. Aglomerasi dan Pertumbuhan Ekonomi Regional di Sumatera Selatan Tahun 1993-2002. Disertasi PPs Unsyiah. Banda Aceh.

Tarigan, Robinson. 2004. Perencanaan Pembangunan Wilayah. Bumi Aksara. Jakarta.

Tim Studi P4W-IPB. 2001. Studi Evaluasi Pengelolaan Pengembangan Program KSP. Bogor.
Tim Pembina Pusat. 1999. Konsep Pengembangan Kawasan Sentra Produksi (P-KSP). Jakarta.

Wammali, S. dan W. Khan. 1972. Conceptual and Methodological Dimension of Central Place Theory. National Institute of Community Development. Hyderabad.

Yudhoyono, Susilo Bambang. 2004. Pembangunan Pertanian dan Perdesaan Sebagai Upaya Mengatasi Kemiskinan dan Pengangguran : Analisis Ekonomi-Politik Kebijakan Fiskal. Disertasi PPs IPB. Bogor.

Yusdja, Yusmichad. Ilham, Nyak,. dan Sayuti, Rosmijati. 2004. Tinjauan Penerapan Kebijakan Industri Ayam Ras: Antara Tujuan dan Hasil. Forum Penelitian Agro Ekonomi. Volume 22 No 1, Juli 2004. Halaman 22-36. 